\begin{tabular}{|c|c|c|}
\hline Beitr. Ent. & Berlin & ISSN 0005-805X \\
\hline $\mathbf{5 0}(2000) 1$ & S. $179-191$ & 11.04 .2000 \\
\hline
\end{tabular}

\title{
Species-specific foraging strategies of the syntopical and synchronous bees Panurgus calcaratus (SCOPOLI, 1763) and Dasypoda hirtipes (FABRICIUS), 1793
}

\section{(Hymenoptera: Apidae)}

With 4 figures

EVA-MARIA LEVERMANN, IngE BISCHOFF und ThOMAS WAGNER

\section{Summary}

Two ground-nesting, oligolectic bee species, Panurgus calcaratus (SCOPOLI, 1763) and Dasypoda hirtipes (FABRICIUS, 1793), which are syntopical and synchronous, were studied in the Wahner Heide Nature Reserve (Rhineland, Germany). To study mechanisms of ecological separation or niche differentiation the species-specific seasonal and diurnal rhythms and the foraging strategies were examined. In addition to provisioning behaviour, their oligolecty was examined by analysing pollen samples from females after flower-visiting and by observations of the bees on their pollen sources. Both species exclusively visit yellow, photonastic liguliflorous Asteraceae as pollen sources, prefer to construct their nests on sandy soils with poor vegetation and are active from the beginning of July until the end of August. Analysed samples show pollen grains belonging to yellow liguliflorous Asteraceae only and there was no specialisation within the oligolecty on certain plant species. Collection of pollen is limited by the photonastic flowers of the pollen sources, and the bee activity is mainly influenced by climatic factors like light intensity, cloudcover, and air-temperature. The diurnal activity period of Dasypoda hirtipes is much longer and this species is active at lower temperatures. The specific diurnal and seasonal behaviour and activity rhythm of the two bee species are discussed with regard to body size and coloration, the ability of heat absorption and reflection, risk of overheating, and ecto- and heterothermal effects to heat budgets. Each species follows its own foraging strategy which is mainly influenced and limited by ultimate factors as the bees " physiology under the given abiotic conditions. Neither nesting sites nor pollen and nectar resources are limited and consequently there is no evidence for competition between both species.

\section{Keywords}

Interspecific competition; oligolecty; optimal foraging strategies; photonasty; resource partitioning; separation mechanisms.

\section{Zusammenfassung}

Die Sammelstrategie der beiden endogäischen, oligolektischen syntop und synchron auftretenden Wildbienenarten Panurgus calcaratus (SCOPOLI, 1763) und Dasypoda hirtipes (FABRICIUs, 1793) wurden im Naturschutzgebiet Wahner Heide (Rheinland, BRD) untersucht. Saisonale und diurnale Rhythmik sowie die Sammelstrategien beider Arten wurden erfaßt, um eventuell bestehende Trennungsmechanismen oder Nischendiffenzierung aufzudecken. Neben dem Verproviantierungsverhalten der Bienen wurde die Oligolektie durch Pollenentnahme von Weibchen und durch Beobachtung an den Pollenquellen überprüft. Beide Arten nutzen ausschließlich gelbe, photonastische, zungenblütige Asteraceae als Pollenquellen, präferieren sandige Flächen mit geringer Vegetation als Nistplatz und sind von Anfang Juli bis Ende August aktiv. Eine Spezialisierung innerhalb der Oligolektie auf einzelne Arten zungenblütiger Asteraceae konnte nicht erkannt werden. Dasypoda hirtipes wies eine allgemein längere diurnale Aktivität auf 
und war zudem auch bei geringeren Temperaturen noch aktiv. Die Pollensammelaktivitäten werden bei beiden Arten maßgeblich von den photonastischen Pollenquellen limitiert. Desweiteren ist die Bienenaktivität von klimatischen Faktoren wie Lichtintensität, Bewölkung und Lufttemperatur abhängig. Artspezifische diurnale und saisonale Verhaltensweisen und Aktivitätsrhythmen werden im Hinblick auf Körpergröße und -farbe, Hitzeabsorptions- und Reflektions-Fähigkeit, Überhitzungsgefahr sowie Effekte der Ekto- und Heterothermie auf den Wärmehaushalt diskutiert. Jede Art verfolgt eine eigene Sammelstrategie, welche hauptsächlich durch ultimative Faktoren wie die Physiologie der jeweiligen Bienenart beeinflußt und zugleich limitiert wird. Weder Nistplatzangebot noch die Ressourcen Pollen oder Nektar sind im Untersuchungsgebiet begrenzt, so daß keine Evidenz für Konkurrenz zwischen den beiden Arten besteht.

\section{Introduction}

More than a century ago, MÜLLER (1884) stated that Dasypoda hirtipes (FABRICIUS, 1793) and Panurgus calcaratus (SCOPOLI, 1763) (Hymenoptera: Apidae) are oligolectic, i.e. using the same plants as pollen-sources. This and other ecological similarities such as nesting sites and seasonal activities were investigated in subsequent studies (KNERER 1980, TENGÖ et al. 1988, WESTRICH 1990), and liguliflorous Asteraceae were found to be the preferred pollen resources (LIND 1968, MÜNSTER-SWENDSEN 1968, MEYER-HOLZAPFEL 1984, TENGÖ et al. 1988, SANTOMAURO 1993). According to LINSLEY \& MACSWAIN (1957) bees, whose females collect pollen only from one or few closely related plant species, are called oligolectic. Only in times when the 'species-specific' pollen-sources are not available, may the specialists shift to other plant species. Usually, the spectrum of plants used as nectar resources is much wider (LINSLEY 1958, BAKER \& HURD 1968, EICKWORT \& GINSBERG 1980). Oligolecty on photonastic pollen-sources is often correlated with synchronous diurnal activity of the female bees. In addition especially abiotic factors such as air temperature, cloudiness, solar radiation and humidity are of high importance for the bees' activity (LIND 1968, MÜLLER 1884, SANTOMAURO 1993).

Their behaviour is also strongly influenced by the physiological and morphological preconditions. Size appears to be of great importance for cell-provisioning and reproductive success (AlCOCK 1979, STONE et al. 1988, STONE \& Willmer 1989; STONE 1993 a, b, STONE 1994; STONE et al, 1995). For many Sphecidae and Apidae, the relation between female size and the potential provisioning-load is a crucial characteristic (MARLIANI 1997, VON AsIS et al. 1996, JOHNSON 1990). Also the difference in size between $P$. calcaratus and $D$. hirtipes suggests differences in their provisioning behaviour.

\section{Materials and Methods}

\section{Study site}

The study was performed in the Geisterbusch, Wahner Heide, to the northeast of the airport Cologne/Bonn. Since 1961, this area is protected as a Nature Reserve and is also used as military training area. These activities lead to a permanent disturbance of the vegetation and cause patchy open areas. It also leads to the extension of highly competitive plant species like Rubus fruticosus agg., Calamagrostis epigeios (L.) ROTH and Pteridium aquilinum (L.) KUHN. On the dry and sandy soils the typical landscape is open with only scarce vegetation consisting of Hypericum perforatum L., Hypochoeris radicata L., Leontodon nudicaulis (L.) BANKS, Leontodon autumnalis L., Crepis capillaris (L.) WALL., Hieracium pilosella, and clumps of Cichorium intybus L., Cirsium arvense (L.) SCOP., Calluna vulgaris (L.) HULL, and Solidago canadensis (L.).

The climate is humid-oceanic (WEBER 1989), the amplitude of annual temperature is $17^{\circ} \mathrm{C}$, and annual mean temperature is the highest of whole Germany with $9.5^{\circ} \mathrm{C}$. Annual mean precipitation is $804 \mathrm{~mm}$. 


\section{Data gathering}

Air and ground temperature as well as relative humidity were measured by three dataloggers (Tinytalk IP 68-Logger) for each permanent site. Data on climate at the climatological stations of the airport Cologne/Bonn were examined to obtain information about the conditions between study days. Field weather conditions regarding cloudcover, precipitation and the subjective ambient or ,feel-temperature" were estimated at the beginning, middle and at the end of each daily observation (Tab. 1).

Tab. 1: Encoding of the estimated „feel temperature" as measurement of weather conditions.

\begin{tabular}{|c|l|}
\hline $\begin{array}{l}\text { Wheather } \\
\text { condition }\end{array}$ & Definition \\
\hline 0 & sunny, clear, hot \\
\hline 1 & sunny, clear, warm \\
\hline 2 & (slightly) cloudy, but partly sunny and particularly warm or hot \\
\hline 3 & slightly cloudy, but without sunny periods, cooler \\
\hline 4 & cloudy, less warm \\
\hline 5 & dense clouds, no sun, cool \\
\hline 6 & dense clouds, light rain \\
\hline 7 & dense clouds, rain \\
\hline
\end{tabular}

\section{Methods of observation}

The study performed in 1997. From the beginning of June 1997 the study area was periodically observed in search for the first flying individuals. The first captures of females of $D$. hirtipes were marked individually on their thorax with small Opalith-plates, but later (nesting) females of both species were individually marked with varnish colours (edding 780) on the thorax. The nests were marked with nails in the 'owners' colour.

The nest condition (open or closed) was checked at the beginning of a daily observation period. Nest entrances were covered by glass jars to prevent bees from disappearing nest or returning from pollen collection, respectively, in order that their load could be estimated. If the bees returned without any pollen this was termed nectar flight. The time of nest opening and closing were noted to estimate total daily activity, whereas the time-span from first departure to the last return marked the period of the daily foraging activity. Pollen-sources of $D$. hirtipes and $P$. calcaratus in the area were compared with pollen samples from the bees using slide preparations of pollen (WESTRICH 1989). Such bees were shaken out in a tube with $5 \mathrm{ml}$ aqua dest. and immediately removed from the tube afterwards. Behaviour of the wet bees was observed but foraging activity of the probationers was not evaluated further that day. Acetolysis was necessary (cf. ERDTMANN 1954, 1960) in order to prepare the pollen samples for analysis under the light-microscope. The (mean) quantity of one pollen load was compared with the quantity of pollen potentially being provided by the food plants, the number of anthers per inflorescence of the preferred food plants was estimated to calculate the mean number of anthers per inflorescence. The species spectrum of preferred pollen sources and the mean species-specific collecting time per inflorescence was also estimated by observation. 


\section{Results}

\section{Diurnal activity pattern}

The diurnal rhythms of nesting females showed strong interspecific differences (Fig. 1). Median time for nest opening of $D$. hirtipes is $08: 31 \mathrm{~h}$, the species has 8 foraging flights and closes the nest at about 13:20h. P. calcaratus opens the nest at $09: 45 \mathrm{~h}$, makes on an average only 5 foraging flights and closes the nest much earlier at 12:20h. The temporal activity period of $P$. calcaratus is within that of $D$. hirtipes.

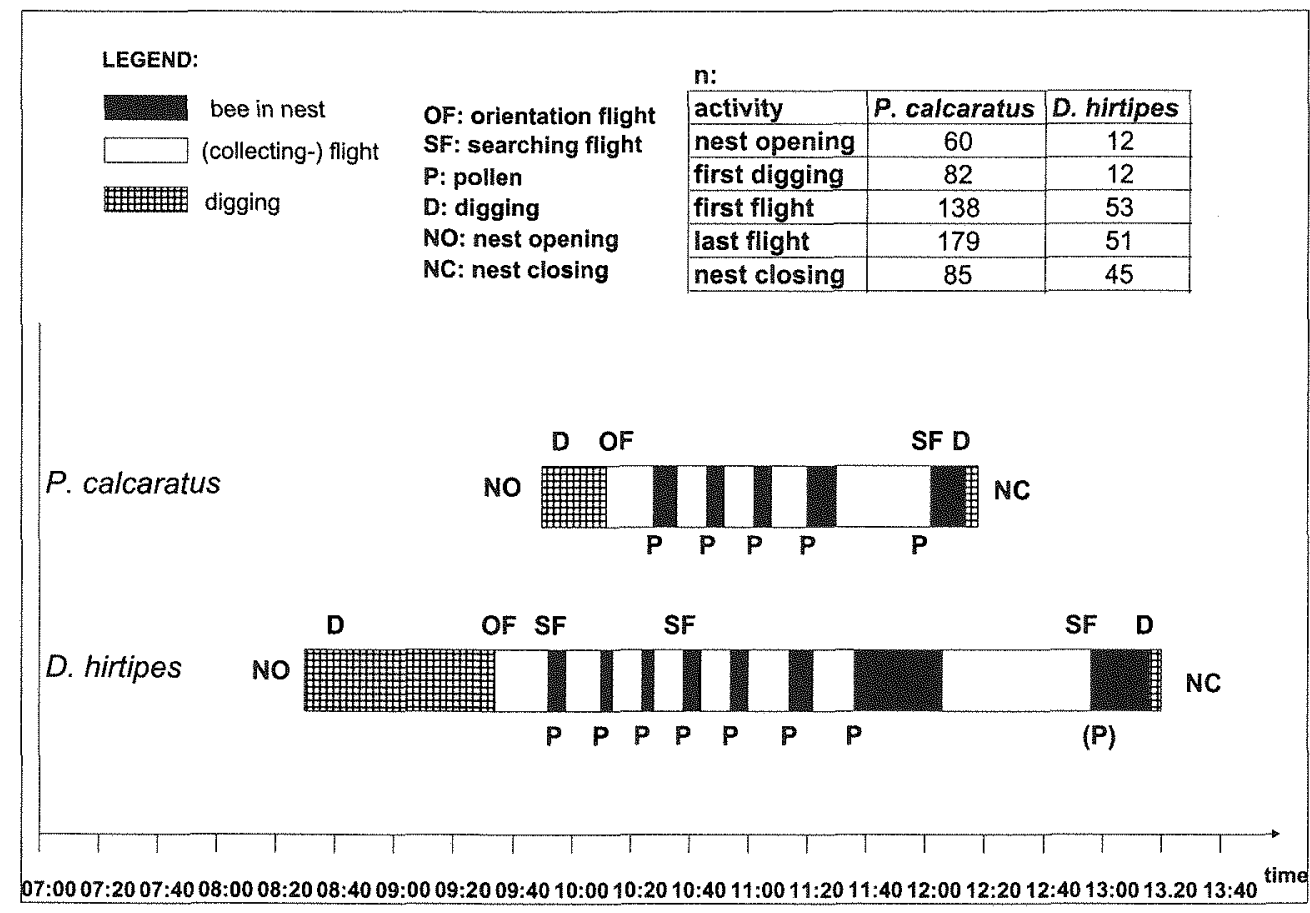

Fig. 1: Species-specific diurnal activity of nesting $D$. hirtipes and $P$. calcaratus (median data)

Different diurnal activities were combined with species-specific tolerances in temperature (Fig. 2). Both species have the same range of temperature tolerance (Fig. 2), but there are significant differences between them (Tab. 2). Median temperature for nest closing is $1.3^{\circ} \mathrm{C}$ higher for $D$. hirtipes, for nest opening $3.5^{\circ} \mathrm{C}$ lower than for $P$. calcaratus. D. hirtipes starts its activity significantly earlier in the morning, opens the nest at $19.1^{\circ} \mathrm{C}$ and starts her first foraging flight at $20.9^{\circ} \mathrm{C}$. This species is also more tolerant of high temperatures.

The different tolerance of temperature can be also derived from the typical diurnal rhythms (Fig. 1). A single $D$. hirtipes female showed quite different provisioning behaviour on two days of climatic extreme. On 22. VII. (the most atypical day of the whole observation period with heavy clouds and rainfall and a mean temperature of $19^{\circ} \mathrm{C}$ ) the female stayed for about 2.5 hours in its nest after its opening, sometimes burrowing or waiting or making occasional fruitless flying efforts. The bee undertook 5 foraging flights during the more sunny periods of this day, with 10 hours the longest day of the bee activity. Before starting a foraging flight the bee contracted her thoracal muscles for warming up. Similar observations regarding the temporal shift of provisioning activities also were made on several females of $P$. calcaratus. 

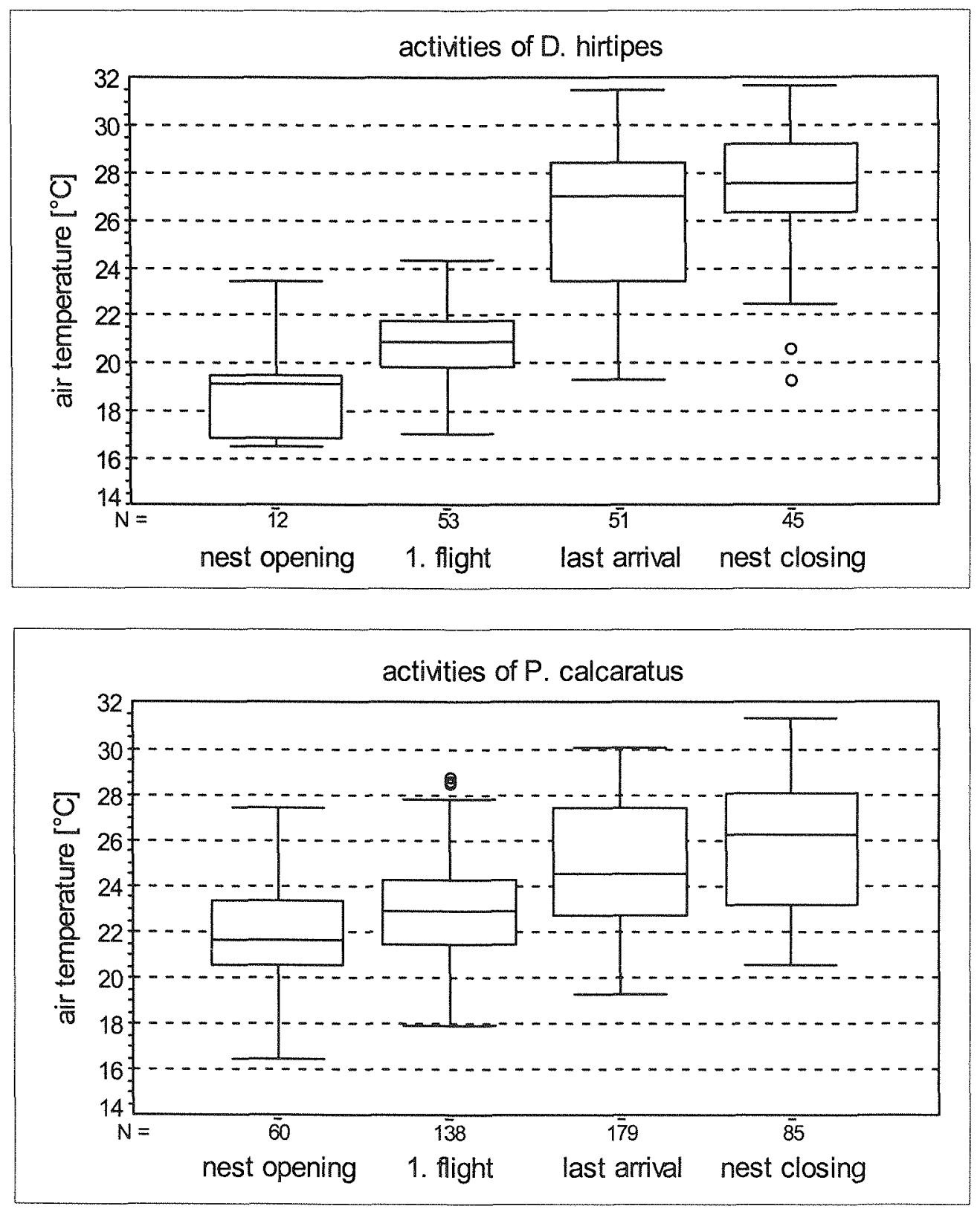

Fig. 2: Activities of $D$. hirtipes and $P$. calcaratus in correlation to air temperature (boundary lines: 1 . and 3. quartil; inside line: median; symbols: extrema)

The activity of the $D$. hirtipes female on the next day was very different. It was the hottest day of that summer with a daily mean temperature of $27.5^{\circ} \mathrm{C}$ and a maximum temperature of $32.2^{\circ} \mathrm{C}$. The nest was already open at $08: 10 \mathrm{~h}$ and digging was finished. During the next 2.5 hours the bee undertook 9 foraging flights with a duration of $9-18 \mathrm{~min}$. After the last and longest flight $(38 \mathrm{~min}$ ) the bee closed the nest to finish her daily activities already at 11:55h. 
Tab. 2: ANOVA of bee's activities influenced by temperature ( $2 \mathrm{~m}$ above ground) between the two species

\begin{tabular}{|l|l|l|l|}
\hline temperature $(2 \mathrm{~m})$ & $\mathrm{F}$ & $\mathrm{p}$ & Consequences \\
\hline nest opening & 23.90 & $<0.001$ & D. hirtipes earlier \\
\hline 1. flight & 34.8 & $<0.001$ & D. hirtipes earlier \\
\hline last arrival & 4,65 & $<0.05$ & D. hirtipes later \\
\hline nest closing & 5,29 & $<0.05$ & D. hirtipes later \\
\hline
\end{tabular}

\section{Correlation of bee and flower activity with abiotic factors}

Beginning and end of photonastic pollen presentation of the food plants correlate with intensity of sun and the presence of clouds, factors which are also very important for the provisioning activities of the bees (Fig. 3). Not only the opening of the inflorescences, but also the first departure of the bees show a significant positive correlation with the conditions. Intensive solar radiation causes an early opening of the pollen sources and an early start of provisioning.

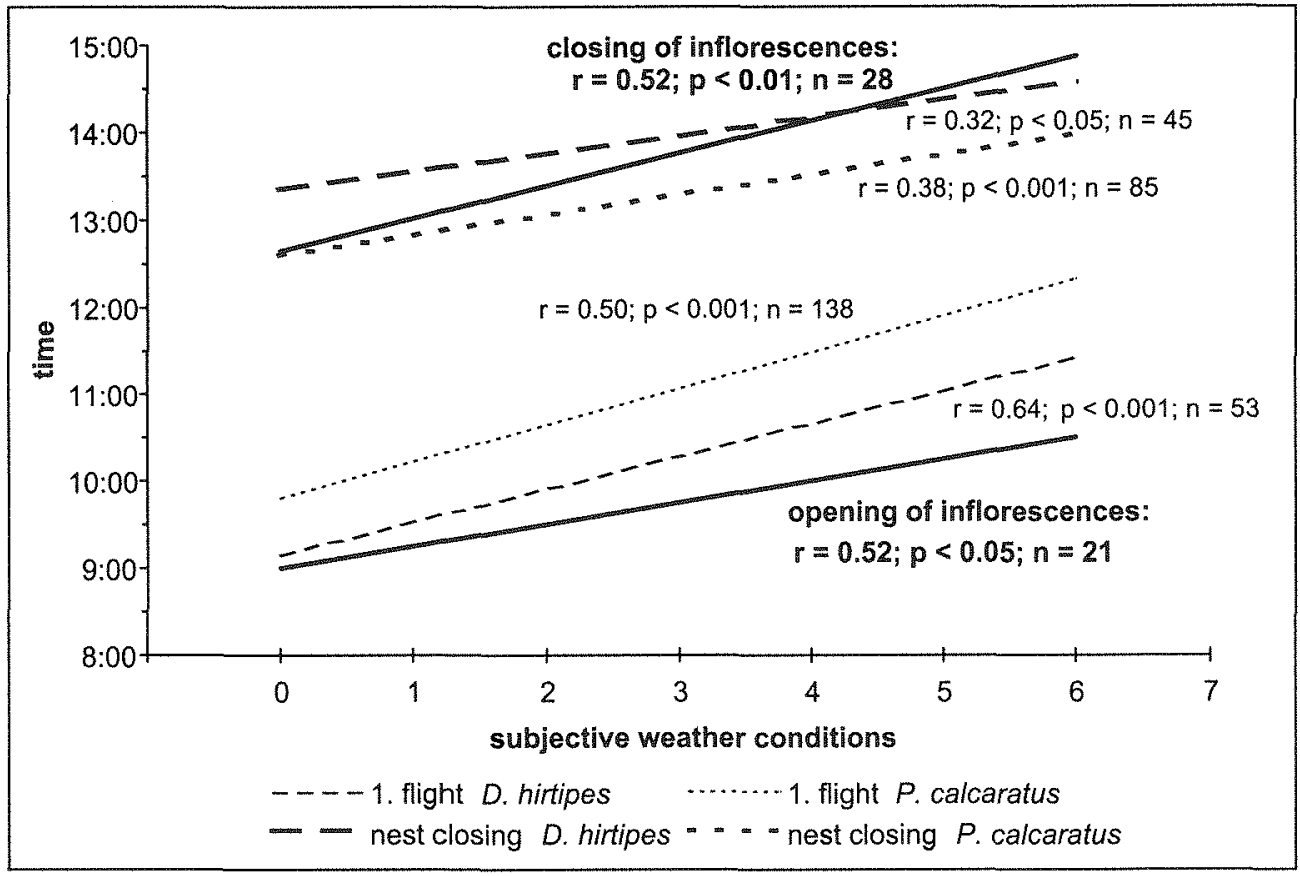

Fig. 3: Correlation between 1. flight and opening of inflorescences, and correlation between closing of nests and inflorescences to weather conditions respectively

Conversely, pollen sources closed earlier and bees finished their foraging activities earlier with decreasing solar intensity. Not only the first but also the last daily activity correlated, sometimes highly significantly, with the respective activity of pollen presentation of plants (Fig. 4). Opening and closing of inflorescences and nests were strongly influenced by temperature and solar radiation. 

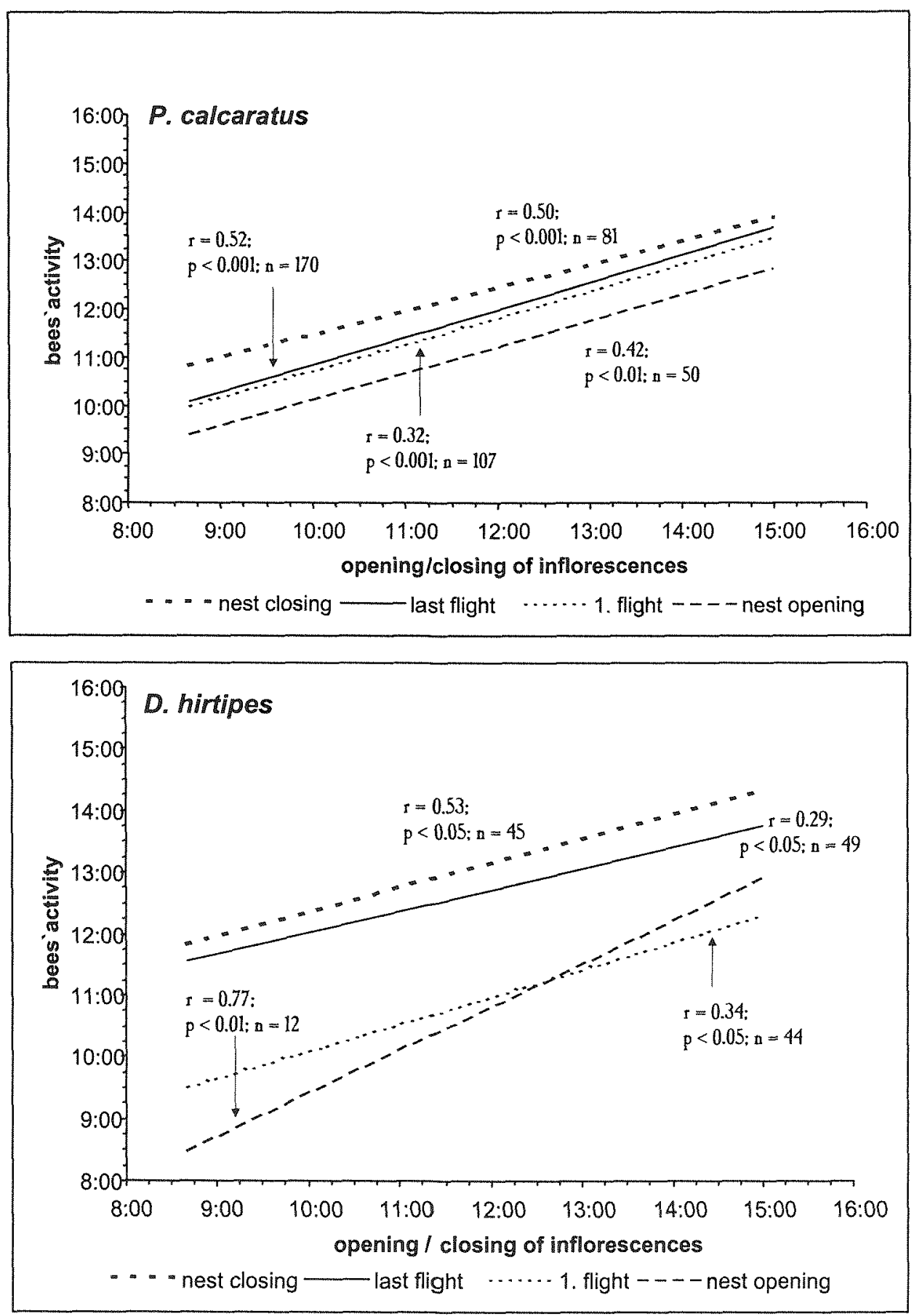

Fig. 4: Correlation between different bee's activities to the opening and closing of inflorescences 


\section{Species-specific foraging strategies}

Pollen samples were taken from $11 \mathrm{D}$. hirtipes and $10 \mathrm{P}$. calcaratus. After comparison with the pollen of the liguliflorous Asteraceae flowering in the study area, Leontodon autumnalis L., Leontodon nudicaulis L., Hypochoeris radicata L., Crepis capillaris (L.) WALLR. and Hieracium pilosella $\mathrm{L}$. were identified as the most important pollen sources. Quantification of pollen showed that Hypochoeris radicata has the highest potential pollen reservoir, which decreases from Leontodon autumnalis, Leontodon nudicaulis, Crepis capillaris to Hieracium pilosella by a factor of 3.8 .

\section{Quantity and quality of the pollen samples}

The assigning of pollen to distinct non-liguliflorous Asteraceae was not possible due to their high palynological similarity. Only the pollen of Centaurea jacea and Cirsium arvense, flowering synchronously in the study area, showed characteristic surface structures and would be distinguished by light-microscoping, but of these or other Asteraceae species there was no pollen in the samples analysed.

The mean number of pollen grains collected per flight was 22.483 in P. calcaratus, the samples of $D$. hirtipes contained on an average 315.680 pollen grains. A correlation between the duration of flight and the number of pollen grains collected was only found in $P$. calcaratus $(\mathrm{r}=-0.667 ; \mathrm{p}<0.05 ; \mathrm{n}=10)$, i.e. after long time flights significantly less pollen were collected than after flights of short duration, whilst in $D$. hirtipes there was a significant correlation between the number of pollen and the order of the flight $(\mathrm{r}=0.6108 ; \mathrm{p}<0.05 ; \mathrm{n}=$ 11 ), that means there was an increase in pollen load from early to late flights.

Tab. 3: Efficiency of pollen collecting of both bee species (hypothetical presentation of $100 \%$ pollen during the whole collecting activity; pollen / inflorescence: 50655 (median)

\begin{tabular}{|c|c|c|c|c|c|c|}
\hline & D. hirtipes & & P. calcaratus & & & \\
\hline & median $(\mathrm{SD})$ & $\mathrm{n}$ & median (SD) & $\mathrm{n}$ & $\mathrm{F}$ & $\mathrm{p}$ \\
\hline $\begin{array}{l}\text { collected pollen/ collecting- } \\
\text { flight }\end{array}$ & $258(301)$ & 11 & $17,8(24,8)$ & 10 & & $<0.01$ \\
\hline $\begin{array}{l}\text { duration of pollen-collecting- } \\
\text { flight [min] }\end{array}$ & $13.0(18.0)$ & 364 & $12.0(15.4)$ & 756 & 268 & $>0.05$ \\
\hline $\begin{array}{l}\text { duration of stay/ inflorescence } \\
\text { [sec] }\end{array}$ & $0.7(2.19)$ & 38 & $5.0(8.74)$ & 320 & 158 & $<0.001$ \\
\hline $\begin{array}{l}\text { number of inflorescences/ } \\
\text { collecting-flight }\end{array}$ & 1114 & & 144 & & & \\
\hline $\begin{array}{l}\text { collected pollen/inflores- } \\
\text { cences }\end{array}$ & 231 & & 123 & & & \\
\hline collected pollen/ second & 331 & & 247 & & & \\
\hline $\begin{array}{l}\text { number of collecting-flights/ } \\
\text { day }\end{array}$ & $8.0(3.05)$ & 36 & $5.0(2.85)$ & 111 & 257 & $<0.001$ \\
\hline profit/inflorescence & $0.0047 \sim 0.5 \%$ & & $0.0024 \sim 0.25 \%$ & & & \\
\hline
\end{tabular}


The highest number of pollen grains could be found after a flight of 9 min for $P$. calcaratus and $10 \mathrm{~min}$ for $D$. hirtipes. Taking numbers of pollen per flight into account, $D$. hirtipes is able to collect on average 14 times more pollen grains than $P$. calcaratus in nearly the same period.

\section{Pollen-collecting efficiency per inflorescence}

$P$. calcaratus stayed an average of $5 \mathrm{~s}$ on each visited inflorescence, while this period is only $0.7 \mathrm{~s}$ for $D$. hirtipes. The duration of stay per inflorescence and the duration of a foraging flight give an estimation of the number of inflorescences visited per flight. Time spent only for flying to and between pollen sources was not estimated. Observations revealed that $P$. calcaratus investigates about $20 \%$ of its total flying time in between flowers while there are no comparable data for $D$. hirtipes, since it was not possible to trace this species once it had left the nest. $P$. calcaratus visited on average 144, and D. hirtipes 1114 inflorescences per flight (Tab. 3). These data allow calculations on the number of pollen collected per inflorescence, which average 231 for $D$. hirtipes, while $P$. calcaratus collects nearly half of this amount (Tab. $3)$. Regarding the potential pollen reservoir per inflorescence, $D$. hirtipes exploits only $0.5 \%$ and $P$. calcaratus only $0.25 \%$ of the total pollen presented by the inflorescence (Tab. 3). Both species are extremely different in their efficiency of collecting pollen: $P$. calcaratus would take an estimated time of $34.2 \mathrm{~min}$ to exploit one inflorescence completely, whilst $D$. hirtipes theoretically only needs $2.6 \mathrm{~min}$ for the same activity.

\section{Discussion}

\section{Diurnal activity, bee size and coloration}

In the study area $P$. calcaratus and $D$. hirtipes are sympatric and synchronous, and there are at least two essential resources for females of both species: yellow, liguliflorous Asteraceae as a pollen-source and sandy soil for nesting. However, both species differ in diurnal phenology and show species-specific strategies of pollen recruitment.

The main cause of these differences is the different range of temperature tolerance of both species. The correlation between the bee body size and the ability of endothermy is an important factor, which permits species to be active even at low temperatures (STONE et al. 1988, STONE \& Willmer 1989, STONE 1993 a, b, STONE 1994, STONE et al. 1995). Conversely, extremely high temperatures also restrict foraging activities (MÜLLER 1884), which was often observed in the summer 1997.

Solar radiation and body size, body colour and surface structure, and the resulting capacity of heat absorption and reflection are of particular importance in this context (WILLMER 1983, KATO 1943). For ectothermal species air and ground temperature is most crucial. Such species are strongly dependent on sunshine, while larger body size and the ability of endothermy allows $D$. hirtipes to start its foraging activities earlier than the smaller $P$. calcaratus. Larger and / or black coloured females are usually active at low temperatures and little solar radiation, whilst individuals foraging at noon in the sun are smaller and lighter or metallic.

While the smaller and black coloured $P$. calcaratus, which is active in a short frame time, represents a typical ectothermal bee whose activity only depends on abiotic factors like solar radiation and temperatures (WILLMER 1983), it is probable that the comparatively larger and light coloured $D$. hirtipes has the capacity to be a facultative endotherm. Observations of myothermical activities under bad weather conditions as on 22.VII. emphasize this (cf. MAY 1979, CASEY 1981, Willmer \& UNWIN 1981, STONE et al. 1988, STONE \& WillmER 1989, StONE 1993 a, b, STONE 1994, STONE et al. 1995, Cossins \& BOWLer 1987). It allows $D$. hirtipes to forage at temperatures which are outside the activity range of $P$. calcaratus. 


\section{Efficiency in pollen recruitment}

The highest amount of nectar and pollen is available in the early morning (WILLMER 1983, MÜNSTER-SWENDSEN 1968), since the number of food competitors increase during the day. For oligolectic bees the time and efficiency of pollen collecting is further restricted by the short period of pollen presentation when a large amount of pollen needs to be collected within a short time. An advantage in visiting only specific pollen sources can be found in the homogenous structure of pollen grains. That of yellow liguliflorous Asteraceae differ only slightly in size, but not in shape, which may optimise the handling and therefore collecting time. Also the pollenkitt, typical for entomophilic plants and particularly abundant in Asteraceae, supports the pollen recruitment. It makes the pollen adhesive and leads to large pollen clusters which may be more easily collected than single pollen grains.

Both bee species have scopae at the hind legs which support the collection of pollen (WESTRICH 1990, MÜLler 1884, BERGMARK et al. 1984). D. hirtipes has much longer scopal hairs and larger scopae. Increasing length and number of the collecting hairs correlates positively with the potential pollen load. This permits $D$. hirtipes to collect and transport large amounts of pollen effectively far away from the nesting site, and makes it much less dependent on local pollen sources (WESTRICH 1990, STRICKLER 1979). P. calcaratus and D. hirtipes differ strongly in their pollen-handling. Whilst the smaller $P$. calcaratus wriggled through the inflorescences (WESTRICH 1990, BISCHOFF 1927, MÜLLER 1884, STRICKLER 1979, SANTOMAURO 1993), $D$. hirtipes hovered from flower to flower (MÜLLER 1884), a phenomen confirmed by the times both species need to visit one plant. While MiCHENER (1954) and ROBERTSON (1941) interpreted this as a hypothesis for the evolution and diversification of specialised bees, this study indicates support models of resource partitioning and the so-called 'optimal foraging strategy' (CODY 1974, COVICH 1974, OSTER \& HEINRICH 1976, OSTER \& WILSON 1978, PYKE et al. 1977, SCHOENER 1971). In addition, specialists spend less time on flights between host plants than do generalists (STRICKLER 1979), a hypothesis which applies to $P$. calcaratus only. The long flight periods and rare observations of $D$. hirtipes collecting near the nesting site were in strong contrast with this. Nevertheless, the foraging strategy of $D$. hirtipes proved to be more efficient regarding the amount of collected pollen per inflorescence and flight. $P$. calcaratus is able to forage the necessary amount of pollen in a way which does not require as much energy as the strategy of $D$. hirtipes regarding the long distance-flights of $D$. hirtipes and its longer period of activity per day. The species-specific relation between body size and length of scopae as well as the interspecific differences of size suggest that $D$. hirtipes possesses morphological preconditions such as longer scopae permitting the transportation of a greater amount of pollen. At the same time these higher amounts of pollen require higher costs for transportation which need to be compensated by an extra nectar flight. Besides the length of scopae the body size itself and correlated abilities of thermoregulation permit a greater quantity of pollen to be collected by $D$. hirtipes. The correlation between size and endothermy or heating rate also applies to the females' capacity for transport, which increases with rising temperature and a corresponding increase in efficiency of the flying muscles (STONE et al. 1988, STONE \& Willmer 1989, STONE 1993a, b, STONE 1994, STONE et al. 1995).

Considering the presence of a great number of pollen sources near the nests, the foraging strategy of $D$. hirtipes appears to be very uneconomical. It is probable that $D$. hirtipes preferred remote places where the host plants were less exposed to the sun than they were at the open nesting site. The exposure of the pollen sources plays an important part in the avoidance of overheating (WILLMER 1983). 


\section{Outlook}

Although pollen is ubiquitously available to both species, the females used it in different ways corresponding to their anatomical-physiological equipment. They are following different strategies of foraging and nesting. For the smaller, black coloured $P$. calcaratus, a probable ectothermal species, the temperature-requirements for foraging activity are of greater significance than pollen supply, females being dependent on an autochtonous temperature at the sites where pollen is available next to the nest. The larger, lighter coloured $D$. hirtipes with temperaturerequirements and activity period that suggest facultative endothermy resp. heterothermy consequently needs more energy which can be achieved only by collecting additionally nectar. Whilst ectothermal species try to minimize their costs, endothermal species struggle for a maximum of profit (WILLMER 1983, WILLMER \& CORBET 1981).

The ecological overlap may result in interspecific competition, but than resources must be limited (RICKLEFF 1980, MADDOCKS \& PAULUS 1987). Considering that the essential resources pollen, nectar and nesting-sites are definitely not limited, there is no evidence of interspecific competition between the two bee species. The species-specific foraging strategies are not suitable to prove competition but are mainly a result of ultimate physiological differences between the two species.

\section{Acknowledgements}

Many thanks to NeIL SPRNGate (Natural History Museum, London), LAWriE SPRINGATE, MANFred KrAEMER (Museum Koenig), and RAINER HUTTERER (Museum Koenig) for their critical and valuable comments on the manuscript. MARTINA STEBICH, BEATE Kubitz, and Mrs. GoßMANN (Inst. für Paläontologie, Universität Bonn), for their help in pollen analysis. SABINE MASLOWSKI, VERENA ROSSMAIER, RUTH SCHELLBERG, and ROBERT TORKA for assistance collecting data in the Wahner Heide. Permission to work in the Wahner Heide was given by „Untere Landschaftsbehörde, Rhein-Sieg-Kreis“, and „Belgische Streitkräfte in Deutschland“.

\section{References}

ALCOCK, J. 1979: The relation between body size and provisioning behavior in the bee Centris pallida (Hymenoptera: Anthophoridae). - J. Kans. Ent. Soc. 52 (3): 623-632.

ASIS, J. D. VON, TORMOS, J. \& GAYUBO, S. F. 1996: Behavior of Philanthus pulchellus (Hymenoptera: Sphecidae) with a description of its mature larva. - Ann. Ent. Am, 89 (3): 452-458.

BAKER, H. G. \& HURD, P. D. 1968: Intrafloral ecology, - A. Rev. Ent. 13: 385-414.

BERGMARK, L.; BORG-KARLSON, A.-K. \& TENGÖ, J. 1984: Female characteristics and odour cues in mate recognition in Dasypoda alcercator (Hymenoptera: Melittidae). - Nova Acta R. Soc. Scient. upsaliensis. Ser. V: C. 3: 137-143.

BISCHOFF, H. 1927: Biologie der Hymenopteren. Bd. VIII. 598 S. - J. Springer Verlag, Berlin.

CASEY, T. M. 1981: Behavioural mechanisms of thermoregulation. - Insect Thermoregulation. B. HEINRICH (Ed.). Wiley-Interscience, New York.

CODY, M. L. 1974: Optimization in ecology. - Science 183: 1156-1164.

COSSINS, A. \& BOWLER, K. 1987: Temperature biology of animals. - Chapman and Hall: London.

Covich, A. 1974: Ecological economics of foraging among coevolving animals and plants. - Ann. Mo. bot. Gdn. 61: 794-805.

EICKWORT, G. C. \& GINSBERG, H. S. 1980: Foraging and mating behavior in Apoidea. - A. Rev. Ent. 25: 421-446.

ERDTMAN, G. 1954: An introduction to pollen ananlysis. - Chronica Bot., Walthman, Massachusetts, USA.

ERDTMAN, G. 1960: The acetolysis method. A revised description. - Svensk bot. Tidskr. 54 (4): 561-564.

JoHnson, M. D. 1990: Female size and fecundity in the small carpenter bee, Ceratina calcarata (ROBERTSON) (Hymenoptera: Anthophoridae), - J. Kans, ent. Soc. 63 (3): 414-419. 
KATO, M. 1943: Ecological notes on the activities of some insects coming to the flowers of „Yatude“, Fatsia japonica, with special reference to the ecological importance of solar radiant energy. - Science Report, Tohoku University, Ser. IV (Biology) 17: 255-262.

KNERER, G. 1980: Panurgus calcaratus SCOPOLI (Hymenoptera: Andrenidae), eine kommunale Biene in Europa. - Zool. Anz. Jena 204: 64-68.

LIND, H. 1968: Nest-provisioning cycle and daily routine of behaviour in Dasypoda plumipes (Hym., Apidae). - Ent. Medder. 36: 343-372.

LINSLEY, E. G. 1958: The ecology of solitary bees. - Hilgardia 27: 543-599.

LINSLEY, E. G. \& MACSWAIN, J. W. 1957: The nesting habits, flower relationships and parasites ofsome North American species of Diadasia. - Wasman J. Biol. 15: 199-235.

MADDOCKs, R. \& PAUlus, H. F. 1987: Quantitative Aspekte der Brutbiologie von Osmia rufa L. und Osmia cornuta LATR. (Hymenoptera, Megachilidae): Eine vergleichende Untersuchung zu Mechanismen der Konkurrenzminderung zweier nahverwandter Bienenarten. - Zool. Jb. Syst. 114: 15-44.

MARLIANI, A. 1997: Elterliche Investition beim Europäischen Bienenwolf Philanthus triangulum F. (Hymenoptera, Sphecidae). - Diploma Thesis, University of Bonn.

MAY, M. L. 1979: Insect thermoregulation. - A. Rev. Ent. 24: 313-349.

MEYER-HOLZAPFEL, M. 1984: Zur Ethologie des Männchens der Trugbiene (Panurgus banksianus KIRBY) (Hymenoptera, Apidae). - Z. Tierpsychol. 64: 221-252.

MiCHENER, C. D. 1954: Bees of Panama. - Bull. Am. Mus. nat. Hist. 104: 1-175.

MÜller, H. 1884: Ein Beitrag zur Lebensgeschichte der Dasypoda hirtipes. - Verhdl. naturhist. Verein d. Rheinlande 5 (1): 1-52.

MÜNSTER-SWENDSEN, M. 1968: On the biology of the solitary bee Panurgus banksianus KIRBY (Hymenoptera, Apidae), including some ecological aspects. - Yb. R. Vet. Agr. Coll. Copenhagen: 215-241.

OSTER, G.F. \& HEINRICH, B. 1976: Why do bumble-bees major? A mathematical model. - Ecol. Monogr. 46: 129-133.

OSTER, G. F. \& WILSON, E. O. 1978: Caste and ecology in the social insects. Monogr. in Pop. Biol. 12. Princton Univ. Press: Princeton. 352 S.

PYKe, G. H.; PUlliam, H. R. \& ChARNOV, E. L. 1977: Optimal foraging: A selective review of theory and tests. - Quart. Rev. Biol. 52: 137-153.

ROBERTSON, C. 1914: Origin of oligotrophy of bees. - Entomological News 25: 67-73.

SANTOMAURO, G. 1993: Reproduktionsbiologie der kommunal nistenden Bienenarten Andrena jacobi und Panurgus calcaratus (Andrenidae), insbesondere Sammelaktivität, Trachtpflanzenspezialisierung und ontogenetische Volatilmuster. - Diploma Thesis, University of Tübingen.

SCHOENER, T. W. 1971: Theory of feeding strategies. - A. Rev. Ecol. Syst. 2: 369-404.

STONE, G. N. 1993a: Endothermy in the solitary bee Anthophora plumipes: Independent measures of thermoregulatory ability, costs of warm-up and the role of body size. - J. exp. Biol. 174: 299320.

STONE, G. N. 1993b: Thermoregulation in four species of tropical solitary bees: the role of size, sex and altitude. - J. comp. Physiol. B. Biochem. Syst. envir. Physiol. 163: 317-326.

STONE, G. N. 1994: Activity patterns of females of the solitary bee Anthophora plumipes in relation to temperature, nectar supplies and body size. - Ecol. Ent 19: 177-189.

STONE, G. N.; AMOS, J. N.; STONE, T. F.; KNIGHT, R. L.;GAY, H. \& PARROT, F. 1988: Thermal effects on activity patterns and behavioural switching in a concours of foragers on Stachytarpheta mutabilis (Verbenaceae) in Papua New Guinea. - Oecologia 77: 56-63.

STONE, G. N. \& WILLMER, P. G. 1989: Warm-up rates and body temperatures in bees: The importance of body size, thermal regime and phylogeny. - J. exp. Biol. 147: 303-328.

STONE, G. N.; LODER, P. M. J. \& BLACKBURN, T.M. 1995: Foraging and courtship behaviour in males of the solitary bee Anthophora plumipes (Hymenoptera: Anthophoridae): Thermal physiology and roles of body size. - Ecol. Ent. 20: 169-183.

STRICKLER, K. 1979: Specialization and foraging efficiency of solitary bees. - Ecology 60 (5): 998-1009.

TENGÖ, J.; ERIKSSON, J.; BorG-Karlson, A.-K.; SMTth, B. H. \& DobSON, H. 1988: Mate locating strategies and multimodal communication in male mating behavior of Panurgus banksianus und P.calcaratus (Apoidea, Andrenidae). - J. Kans. ent. Soc. 61 (4): 388-395. 
WEBER (Ed.) 1989: Die Wahner Heide. Eine rheinische Landschaft im Spannungsfeld der Interessen. Rheinland Verlag, Köln.

WESTRICH, P. 1990: Die Wildbienen Baden-Württembergs. Bd. I/II. - Eugen Ulmer Verlag, Stuttgart.

WILLMER, P. G. 1983: Thermal constraints on activity patterns in nectar-feeding insects. - Ecol. Ent. 8: 455-469.

WILlMER, P. G. \& CORBET, S. A. 1981: Temporal and microclimatic partitioning of the floral resources of Justicia aurea amongst a concourse of pollen vectors and nectar robbers. - Oecologia 51: 67-78.

WILLMER, P. G. \& UNWIN, D. M. 1981: Field analysis of insect heat budgets: reflectance, size and heating rates. - Oecologia 50: 250-255.

\author{
Anschrift der Verfasser: \\ EVA-MARIA LEVERMANN, INGE BISCHOFF \& THOMAS WAGNER \\ Zoologisches Forschungsinstitut \\ und Museum Alexander Koenig \\ Adenauerallee 160 \\ D - 53113 Bonn \\ Deutschland
}

\title{
Besprechungen
}

DAVIS, D. R. Ochsenheimeriidae. In: Lepidopterorum Catalogus (New Series), vol. 5, Yponomeutoidea, Fascicle 48. - Assoc. Tropic. Lepid. \& Scient. Publ.: Gainesville, 1998. - 12 p., 1 Taf.

HEPPNER, J. B. Tineodidae. In: Lepidopterorum Catalogus (New Series), vol. 8, Pterophoroidea, Fascicle 61. - Assoc. Tropic. Lepid. \& Scient. Publ.: Gainesville, 1998. - 8 p., 1 Taf.

SCOBLE, M. J. Hedylidae. In: Lepidopterorum Catalogus (New Series), vol. 16, Geometroidea, Fascicle 93. - Assoc. Tropic. Lepid. \& Scient. Publ.: Gainesville, 1998. - 8 p., 1 Taf.

Es ist zu begrüßen, dass in der 1989 begonnenen Serie wiederum drei Familien entsprechend den Richtlinien bearbeitet worden sind. Diese Übersicht über den gegenwärtigen Bestand der Taxa bildet eine unverzichtbare Grundlage für alle weiteren Arbeiten innerhalb dieser Gruppen.

Es wäre wünschenswert, wenn in der näheren Zukunft weitere Familien folgen würden. Größere von ihnen sollten, nach Regionen getrennt, zügig behandelt werden.

R. GAEDIKE 